\title{
Precipitation and microphysical processes observed by three polarimetric $X$-band radars and ground-based instrumentation during HOPE
}

\author{
Xinxin Xie $^{1}$, Raquel Evaristo ${ }^{1}$, Clemens Simmer $^{1}$, Jan Handwerker $^{2}$, and Silke Trömel ${ }^{1}$ \\ ${ }^{1}$ Meteorological Institute, University of Bonn, Bonn, Germany \\ ${ }^{2}$ Institute of Meteorology and Climate Research, Karlsruhe Institute of Technology, Karlsruhe, Germany \\ Correspondence to: Xinxin Xie (xxie@uni-bonn.de)
}

Received: 10 February 2016 - Published in Atmos. Chem. Phys. Discuss.: 12 February 2016

Revised: 6 May 2016 - Accepted: 24 May 2016 - Published: 10 June 2016

\begin{abstract}
This study presents a first analysis of precipitation and related microphysical processes observed by three polarimetric X-band Doppler radars (BoXPol, JuXPol and KiXPol) in conjunction with a ground-based network of disdrometers, rain gauges and vertically pointing micro rain radars (MRRs) during the High Definition Clouds and Precipitation for advancing Climate Prediction $\left(\mathrm{HD}(\mathrm{CP})^{2}\right)$ Observational Prototype Experiment (HOPE) during April and May 2013 in Germany. While JuXPol and KiXPol were continuously observing the central HOPE area near Forschungszentrum Jülich at a close distance, BoXPol observed the area from a distance of about $48.5 \mathrm{~km}$. MRRs were deployed in the central HOPE area and one MRR close to BoXPol in Bonn, Germany. Seven disdrometers and three rain gauges providing point precipitation observations were deployed at five locations within a $5 \mathrm{~km} \times 5 \mathrm{~km}$ region, while three other disdrometers were collocated with the MRR in Bonn. The daily rainfall accumulation at each rain gauge/disdrometer location estimated from the three $\mathrm{X}$-band polarimetric radar observations showed very good agreement. Accompanying microphysical processes during the evolution of precipitation systems were well captured by the polarimetric X-band radars and corroborated by independent observations from the other ground-based instruments.
\end{abstract}

\section{Introduction}

In the frame of the project "High Definition Clouds and Precipitation for advancing Climate Prediction" $\left(\operatorname{HD}(\mathrm{CP})^{2}\right)$, which aims at evaluating and improving the accuracy of climate models in relation to cloud and precipitation processes, the $\mathrm{HD}(\mathrm{CP})^{2}$ Observational Prototype Experiment (HOPE) was conducted during April and May 2013 within the study area of the Transregional Collaborative Research Centre 32 (Simmer et al., 2015) in the vicinity of the Jülich ObservatorY for Cloud Evolution (JOYCE) in Germany (Löhnert et al., 2015). HOPE was conducted in order to provide observations for high-resolution climate models and to improve our understandings of cloud and precipitation processes.

An array of ground-based instruments deployed during HOPE provided comprehensive cloud and precipitation process observations. In this study we concentrate on the precipitation monitoring instruments. Three polarimetric X-band Doppler radars installed in Bonn (BoXPol) and in the vicinity of the JOYCE site (JuXPol and KiXPol) were operated together to continuously monitor 3-D precipitation patterns in order to obtain a holistic view of precipitating systems from micro- and macrophysical perspectives. BoXPol and JuXPol were installed at a distance of $48.5 \mathrm{~km}$ from each other and were operated by the Meteorological Institute of the University of Bonn and the TERENO program of the Helmholtz Association (http://teodoor.icg.kfa-juelich.de; Zacharias et al., 2011), respectively (see Diederich et al., 2015a, for details on both radars), while KiXPol, which was $\sim 9.6 \mathrm{~km}(\sim 50.6 \mathrm{~km})$ away from JuXPol (BoXPol), was deployed by the Karlsruhe Institute of Technology (KIT). A network composed of rain 
gauges and disdrometers measured local precipitation, and collocated micro rain radars (MRRs) simultaneously measured vertical profiles of precipitation and raindrop size distributions (DSDs).

Dual-polarization radars provide multiparameter measurements, which improve quantitative precipitation estimation (QPE) compared to single polarization radars (Zrnić and Ryzhkov, 1999; Zhang et al., 2001; Brandes et al., 2002; Ryzhkov et al., 2014). A thorough comparison of retrieval algorithms for rainfall estimation using polarimetric observables for the HOPE area can be found, for example, in Ryzhkov et al. (2014) and Diederich et al. (2015b). Many studies have already shown the potential of polarimetric radars to identify fingerprints of macro- and microphysical processes related to the evolution of precipitation systems (Kumjian and Ryzhkov, 2010, 2012; Kumjian et al., 2012; Andric et al., 2013; Kumjian and Prat, 2014), based on the sensitivities of polarimetric observables to particle size, shape, concentration and composition (Bechini et al., 2013; Ryzhkov and Zrnic, 1998; Giangrande et al., 2008). For example, very few large rain drops near the ground or at the leading edge of a rain cell result in a larger mean particle size and induce strong differential reflectivity $\left(Z_{\mathrm{DR}}\right)$ accompanied by small reflectivity $(Z)$, which indicates the occurrence of size sorting (Kumjian and Ryzhkov, 2012). Increasing mean particle sizes due to evaporation and coalescence may enhance $Z_{\mathrm{DR}}$, while $Z$ is reduced during evaporation by the depletion of small rain drops (Kumjian and Ryzhkov, 2010; Li and Srivastava, 2001). $Z, Z_{\mathrm{DR}}$ and specific differential phase $\left(K_{\mathrm{DP}}\right)$ all decrease when large raindrops break up (Kumjian and Prat, 2014). Such information can thus be used to validate cloud and precipitation parameterization schemes.

The paper is structured as follows. Section 2 introduces the instrumentation deployed during HOPE, while Sect. 3 presents the surface rainfall estimated from the radars, in conjunction with disdrometers and rain gauges. Section 4 presents and discusses the development of different precipitation systems and related microphysical processes. Size sorting due to vertical wind shear and coalescence is illustrated via the combination of two X-band polarimetric radars. Another case of size sorting captured by BoXPol and a nearby MRR and disdrometers will also be examined in detail. Finally, observed riming/aggregation signatures will be discussed. Conclusions are given in Sect. 5.

\section{Instrumentation}

\subsection{Three X-band polarimetric radars}

The three polarimetric X-band Doppler radars BoXPol, JuXPol and KiXPol operated at a frequency of $9.375 \mathrm{GHz}$. The topography and the locations of the radars, disdrometers, rain gauges and MRRs are shown in Fig. 1. While JuXPol and KiXPol both performed observations in the vicin-
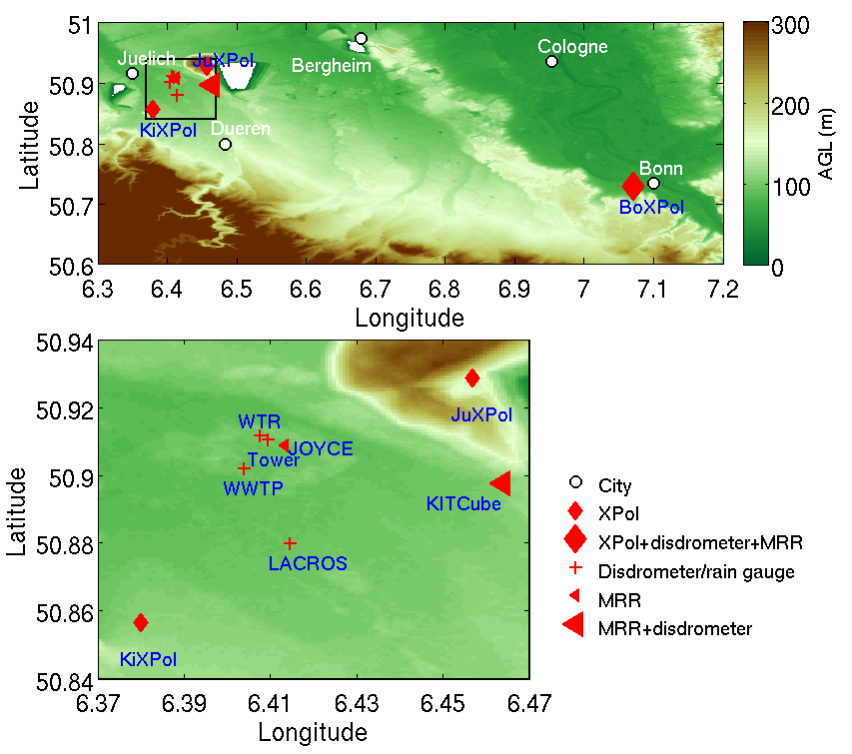

Figure 1. Location of the three polarimetric X-band radars (XPol) and associated micro rain radars (MRRs), rain gauges and disdrometers during HOPE. The bottom panel is an enlargement of the black box area in the top panel. The red diamond markers indicate the locations of the X-band polarimetric radars; the red crosses indicate the locations of disdrometers and/or rain gauges at the sites of LACROS (the Leipzig Aerosol and Cloud Remote Observations System), KITCube (Kalthoff et al., 2013), a wastewater treatment plant (WWTP), a tower, and a wind-temperature radar (WTR); and the red triangles are the MRR locations at JOYCE and KITCube. White areas (elevations below sea level) are open-pit mines.

ity of Jülich, Germany, BoXPol observed the HOPE area from a distance of about $48.5 \mathrm{~km}$ on the roof of a building next to the Meteorological Institute of the University of Bonn in Bonn, Germany, collocated with one OTT Parsivel and two Thies optical laser disdrometers. The three polarimetric radars provide the standard polarimetric variables observed in a simultaneous transmit and receive (STAR) mode, namely $Z, Z_{\mathrm{DR}}, K_{\mathrm{DP}}$, and $\rho_{\mathrm{HV}}$ (copolar correlation coefficient) in addition to the radial Doppler winds and its variance. Detailed technical specifications of JuXPol and BoXPol can be found in Diederich et al. (2015a) and for KiXPol at http://www.imk-tro.kit.edu/english/5438.php. The calibration bias of the three radars were corrected following Diederich et al. (2015a).

Figure 2 shows the operation duration of the three polarimetric radars during HOPE. BoXPol had technical problems on 15 May 2013 but was functional again at around 08:00 UTC on 16 May 2013. JuXPol performed observations from 5 to 8 April 2013. Afterwards, no measurements were available until 22 April 2013 due to technical problems. From 26 to 29 April 2013, JuXPol only performed range height indicator scans (hereafter referred to as RHIs) at $233.7^{\circ}$ azimuth oriented towards JOYCE every minute. KiXPol started its observations on 3 April 2013 but experienced 


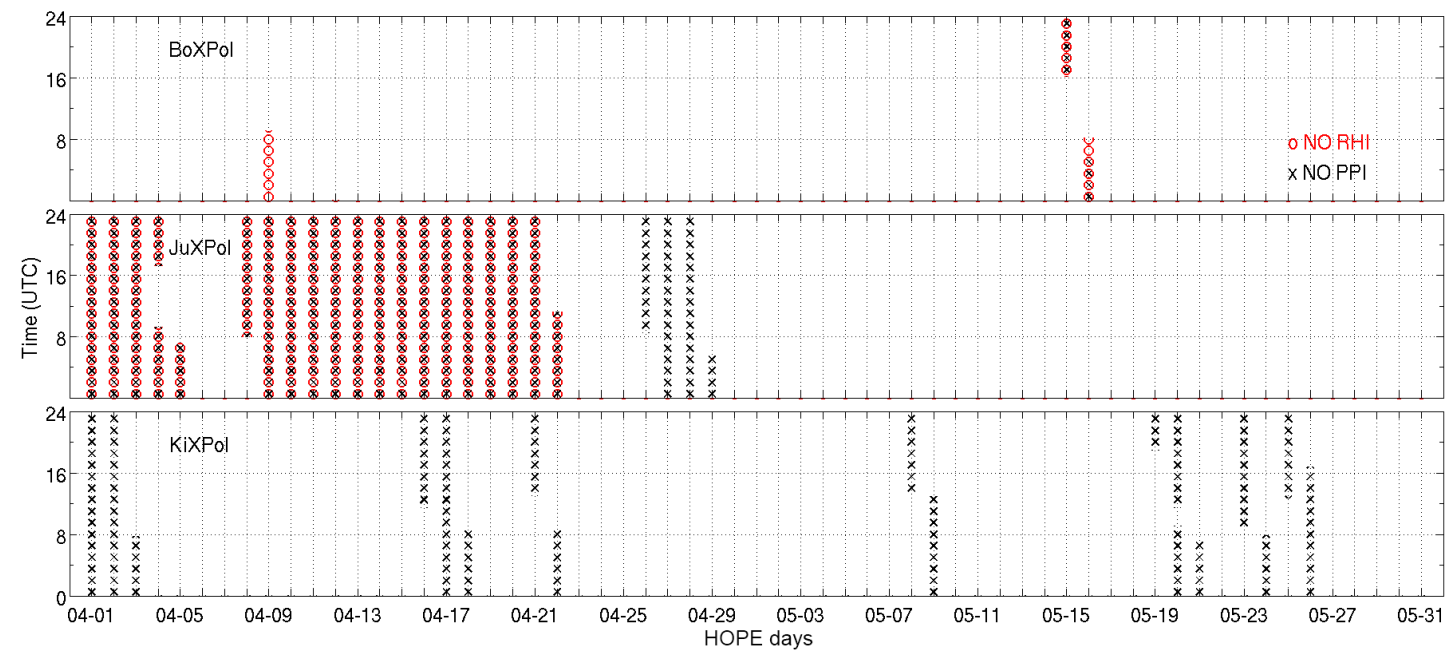

Figure 2. Operation time of the polarimetric X-band radars BoXPol, JuxPol, and KiXPol during HOPE from 1 April to 31 May 2013 , with the red circles indicating "no range height indicator (RHI) available" and the black crosses indicating "no plan position indicator (PPI) available". In May, when KiXPol only performed RHIs on demand, "no PPI" is marked. The general scan strategies of the three polarimetric $\mathrm{X}$-band radars are described in Table 1.

Table 1. The three polarimetric radars during HOPE.

\begin{tabular}{|c|c|c|c|}
\hline & BoXPol & JuXPol & KiXPol \\
\hline Location in latitude/longitude & $50.73^{\circ} / 7.07^{\circ}$ & $50.93^{\circ} / 6.46^{\circ}$ & $50.86^{\circ} / 6.38^{\circ}$ \\
\hline Elevation in ma.s.l. & 100.0 & 310.0 & 106.6 \\
\hline PPIs at elevation in ${ }^{\circ}$ & $\begin{array}{l}1 / 1.5 / 2.4 / 4.5 / 7 / 8.2 / \\
11 / 14 / 18 / 28\end{array}$ & $\begin{array}{l}1 / 2 / 3.1 / 4.5 / 6 / 8.2 / \\
11 / 14 / 18 / 28\end{array}$ & $\begin{array}{l}0.6 / 1.4 / 2.4 / 3.5 / 4.8 / \\
6.3 / 8 / 9.9 / 12.2 / \\
14.8 / 17.9 / 21.3 / 25.4 / 30\end{array}$ \\
\hline RHIs at azimuth in ${ }^{\circ}$ & $\begin{array}{l}\text { 309.5/298.6 } \\
\text { (1-8 April); } \\
\text { 290.0/293.4 } \\
\text { (9 April-31 May) }\end{array}$ & $\begin{array}{l}118.6 \\
\text { (1-25 April); } \\
233.7 \\
\text { (26 April-31 May) }\end{array}$ & on request in May \\
\hline Bird-bath scan & yes & yes & No \\
\hline Radial resolution in $\mathrm{m}$ & $100-150$ & $100-150$ & 250 \\
\hline Scan period & every $5 \mathrm{~min}$ & every $5 \mathrm{~min}$ & every $5 \mathrm{~min}$ \\
\hline $3 \mathrm{~dB}$ beam width & $1.05^{\circ}$ & $1.1^{\circ}$ & $1.35^{\circ}$ \\
\hline Frequency in $\mathrm{GHz}$ & 9.3 & 9.3 & 9.37 \\
\hline Pulse repetition frequency (PRF) in $\mathrm{Hz}$ & $250-1600$ & $25-1600$ & 1000 \\
\hline Antenna rotation rate $\left({ }^{\circ} \mathrm{s}^{-1}\right)$ & $12-28$ & $12-28$ & $12-28$ \\
\hline
\end{tabular}

two malfunctions during that month. In May, when KiXPol was only performing RHIs on request, no plan position indicators (PPIs) were available.

The three polarimetric X-band radars performed volume scans consisting of stacked PPIs with different scan strategies (Table 1). In addition to the volume scans, BoXPol and JuXPol also performed RHIs and vertical scans. A full volume scan of BoXPol and JuXPol takes about $5 \mathrm{~min}$; in this $5 \mathrm{~min}$ interval, RHIs and one vertical scan (bird-bath scan) were performed. The two RHIs of BoXPol were oriented towards JOYCE $\left(290^{\circ}\right)$ and LACROS (293.4 $)$ after 9 April 2013, while JuXPol performed RHIs only towards JOYCE. JuXPol performed RHIs every minute between 26 and 29 April 2013 followed by volume scans with PPIs at 10 elevations and one RHI and vertical scan in 5 min intervals. KiXPol performed only volume scans at 14 elevations every 5 min from April 2013 on (see Table 1). In May 2013, volume scans were interrupted on demand and instead RHIs directed towards the prevailing wind direction were performed with a temporal resolution of $1 \mathrm{~min}$ (Fig. 2). 
Table 2. Information on rain gauges and disdrometers deployed during HOPE.

\begin{tabular}{|c|c|c|c|c|}
\hline $\begin{array}{l}\text { Site } \\
\text { name }\end{array}$ & $\begin{array}{l}\text { Location } \\
\text { (latitude, longitude) }\end{array}$ & $\begin{array}{l}\text { Instrument } \\
\text { (quantity) }\end{array}$ & $\begin{array}{l}\text { Temporal } \\
\text { resolution (s) }\end{array}$ & $\begin{array}{l}\text { Operational } \\
\text { period }\end{array}$ \\
\hline \multirow[t]{2}{*}{ KITCube } & $\left(50.90^{\circ}, 6.46^{\circ}\right)$ & $\begin{array}{l}\text { Joss-Waldvogel disdrometer } \\
\text { (1) }\end{array}$ & 60 & 1 April-31 May 2013 \\
\hline & & OTT Parsivel2 (1) & 60 & 1 April-31 May 2013 \\
\hline LACROS & $\left(50.88^{\circ}, 6.41^{\circ}\right)$ & OTT Parsivel2 (1) & 30 & 2-31 May 2013 \\
\hline \multirow[t]{2}{*}{ WTR } & $\left(50.91^{\circ}, 6.41^{\circ}\right)$ & OTT Parsivel2 (1) & 30 & 17 April-31 May 2013 \\
\hline & & OTT Pluvio (1) & 10 & 17 April-31 May 2013 \\
\hline \multirow[t]{2}{*}{ WWTP } & $\left(50.90^{\circ}, 6.40^{\circ}\right)$ & OTT Parsivel2 (1) & 30 & 17 April-31 May 2013 \\
\hline & & Tipping bucket rain gauge (1) & - & 17 April-31 May 2013 \\
\hline \multirow[t]{3}{*}{ Tower } & $\left(50.91^{\circ}, 6.41^{\circ}\right)$ & OTT Parsivel1 (1) & 30 & 17 April-31 May 2013 \\
\hline & & OTT Parsivel2 (1) & 30 & 17 April-31 May 2013 \\
\hline & & OTT Pluvio (1) & 10 & 17 April-31 May 2013 \\
\hline \multirow[t]{3}{*}{ BoXPol } & $\left(50.73^{\circ}, 7.07^{\circ}\right)$ & OTT Parsivel2 (1) & 30 & 1 April-31 May 2013 \\
\hline & & Thies Disdrometer (2) & 60 & 1 April-31 May 2013 \\
\hline & & OTT Pluvio (1) & 60 & 1 April-31 May 2013 \\
\hline
\end{tabular}

\subsection{Rain gauges, disdrometers, MRRs and radiosondes}

In the vicinity of JOYCE, disdrometers and rain gauges were installed within an area of approximately $25 \mathrm{~km}^{2}$. Seven disdrometers observed surface rain rates and DSDs, while three rain gauges measured rain accumulations (Table 2). The disdrometers and rain gauges close to Jülich are used to evaluate radar-derived QPE. Disdrometer observations at BoXPol, which is $\sim 48.5 \mathrm{~km}$ away from JuXPol, are not taken into account in Sect. 3 when statistically analyzing the precipitation over HOPE, considering the spatial and temporal variability of rainfall.

Three MRRs were deployed close to JOYCE, KITCube and BoXPol. At JOYCE and KITCube, the MRRs measured vertical DSD profiles with a vertical resolution of $100 \mathrm{~m}$; at BoXPol the resolution was $150 \mathrm{~m}$. Due to the near-field scattering effects, MRR observations at the first three gates are not used.

Radiosondes were launched regularly twice per day at KITCube: one at 11:00 UTC and another at 23:00 UTC. Additional radiosondes were launched during intensive observation periods (IOPs).

\section{Precipitation during HOPE}

We first compare QPE derived from the polarimetric radar observations with the observations of the surface network of rain gauges and disdrometers in order to corroborate the consistency and accuracy of both estimates.

Figure 3 shows the daily rain accumulation and precipitation duration averaged over the rain gauge/disdrometer observation sites in the HOPE region (Fig. 1). For rainfall duration, only disdrometer observations are used since the weighing-type rain gauges often indicate small noisy rainlike signals, which prevent accurate information on rainfall duration. According to these observations, the maximum daily rain accumulation was $\sim 14.5 \mathrm{~mm}$, the total rain accumulation during HOPE was $\sim 104.8 \mathrm{~mm}$, and the total rainfall time was $\sim 144 \mathrm{~h}$, i.e., $10 \%$ of the total HOPE period. The rainfall observations at the five locations are in good agreement with each other, as indicated by the bars in Fig. 3, which show the full range of the observations.

According to the disdrometer observations, precipitation during HOPE was not very intense (Fig. 4). The distribution of rain intensities was calculated based on individual measurements of disdrometers over the HOPE area. Rain rates determined at a temporal resolution of 1 min were below $2 \mathrm{~mm} \mathrm{~h}^{-1}$ for more than $88 \%$ of the total precipitation duration, while rain rates above $5 \mathrm{~mm} \mathrm{~h}^{-1}$ were observed for less than $3 \mathrm{~h}$. Only $1 \mathrm{~h}$ of rain rates above $8 \mathrm{~mm} \mathrm{~h}^{-1}$ occurred.

In accordance with the relatively light rainfall events during HOPE, the polarimetric radar observables $Z_{\mathrm{DR}}$ and $K_{\mathrm{DP}}$ were low and quite noisy. Under these conditions, most of the time, we simply used Marshall-Palmer relation for quantitative rainfall estimations (Marshall and Palmer, 1948),

$Z_{\mathrm{H}}=200 R^{1.5}$ (or $R=0.029 Z^{0.67}$ ),

where $Z_{\mathrm{H}}$ (in $\mathrm{mm}^{6} \mathrm{~m}^{-3}$ ) is the radar reflectivity for horizontal polarization in linear scale and $R$ is the rain rate in $\mathrm{mm} \mathrm{h}^{-1}$.

Since Eq. (1) tends to overestimate stronger rain intensities (Zrnić et al., 2000; Trömel et al., 2014b), the $R-K_{\mathrm{DP}}$ relation is employed for rain rate estimation when $Z_{\mathrm{H}}$ is above $37 \mathrm{dBZ}$, i.e., when the instantaneous rain rate is above $8 \mathrm{~mm} \mathrm{~h}^{-1}$ (Diederich et al., 2015b; Ryzhkov et al., 2014). 


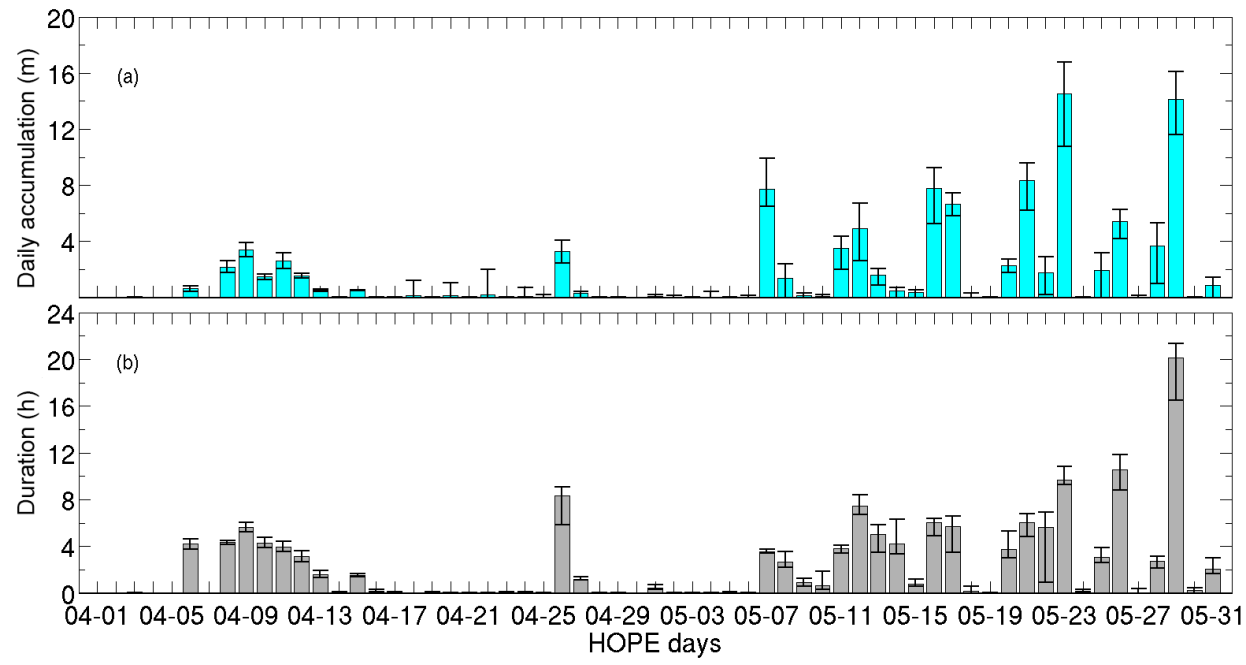

Figure 3. (a) Daily rainfall accumulation during HOPE. The height of the columns indicates the mean value, while the bars indicate the range of the maximum and minimum rain accumulations observed by the three rain gauges and seven disdrometers at the five station locations (Fig. 1). (b) Daily precipitation duration derived only from the seven disdrometers (see discussion in the text). Again, the bars denote the range of the observations.

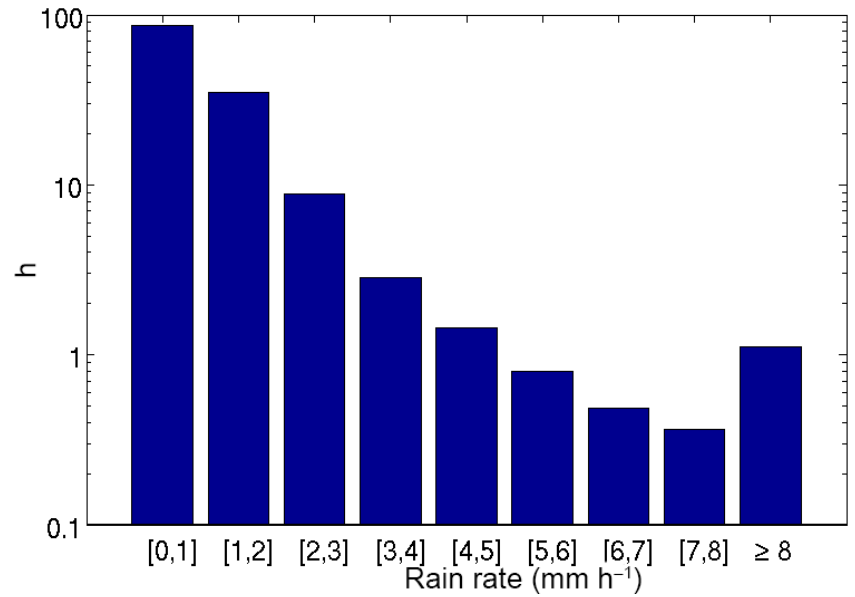

Figure 4. Distribution of rain intensities observed over $1 \mathrm{~min}$ by the disdrometers in the inner HOPE area.

$K_{\mathrm{DP}}$ is independent of calibration and unaffected by attenuation (Ryzhkov et al., 2014). Thus, following Diederich et al. (2015b) and Ryzhkov et al. (2014), in this case the rain rate is determined by

$R=16.9 K_{\mathrm{DP}}^{0.801}$ if $K_{\mathrm{DP}}>0$,

where $K_{\mathrm{DP}}$ is the specific differential phase $\left({ }^{\circ} \mathrm{km}^{-1}\right)$ and filtered from polarimetric radar measurements following Hubbert and Bringi (1995).

Radar bins with copolar correlation coefficient $\rho_{\mathrm{HV}}<0.75$ have been neglected in order to eliminate the ground clutter contamination. For JuXPol and KiXPol, observations at elevations 4.5 and $3.5^{\circ}$, respectively, are used to calculate the rain rates and avoid the possible impacts from a $120 \mathrm{~m}$ height

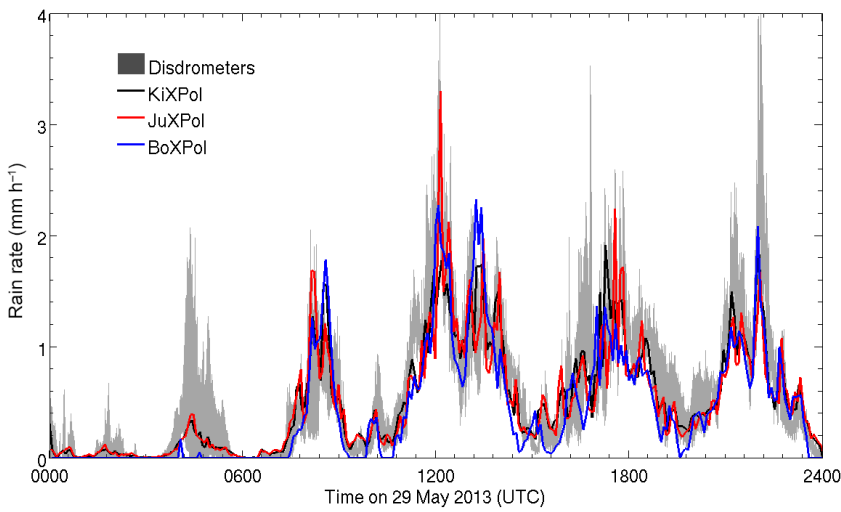

Figure 5. Time series of rain rates derived from observations of the seven disdrometers and the three polarimetric radars on 29 May 2013. The shaded gray area indicates the range of rain rates observed by the disdrometers with 1 min temporal resolution in the HOPE area, while the rain rate from the three polarimetric radar observations is calculated at the radar gates that are coincident with disdrometer locations and also averaged over the five disdrometer locations.

meteorological tower at Forschungszentrum Jülich, while an elevation of $1^{\circ}$ is chosen for BoXPol rainfall estimation since the radar beam at longer distance is less affected by the ground clutter and certainly overshoots the meteorological tower. $Z$ and $Z_{\mathrm{DR}}$ attenuation along each radial is neglected since the rain intensities were generally low over the HOPE area. The mean beam diameter of BoXPol over the HOPE area is around $850 \mathrm{~m}$, which is almost 10 times larger than that of JuXPol and KiXPol, and its beam height $(\sim 860 \mathrm{~m})$ is about 2 times larger compared to JuXPol and KiXPol. 
Figure 5 compares, as an example, the mean rain rates derived from the three X-band polarimetric radar over the five disdrometer locations with the disdrometer observations for 29 May 2013. Precipitation fell intermittently, with five more intense periods separated by short periods of no rain or very low rain rates and maximum rain rates between 1 and $3 \mathrm{~mm} \mathrm{~h}^{-1}$. In general, the variability in the radar-derived surface precipitation matches the disdrometer measurements very well. JuXPol and KiXPol are in better agreement with the surface measurements than BoXPol for the very low rain rates, which probably suffers from the effects of non-uniform beam filling effects due to the much larger distance from the HOPE area (Giangrande and Ryzhkov, 2008) and higher altitude of sampling volume of BoXPol.

Daily accumulated rainfall estimated by the three polarimetric radars is compared with the observations of rain gauges and disdrometers in Fig. 6. Both estimates are very consistent, as indicated by correlations above 0.93 . As for 29 May 2013, BoXPol estimates result in lower daily accumulations than for the other two radars, again probably caused by beam broadening (Giangrande and Ryzhkov, 2008) and the high altitude of the sampling volume of BoXPol over the HOPE area.

With a range resolution of $150 \mathrm{~m}$ (BoXPol and JuXPol) and $250 \mathrm{~m}$ (KiXPol) and a beam diameter of approximately $87 \mathrm{~m}$ (KiXPol and JuXPol) and $850 \mathrm{~m}$ (BoXPol) over the HOPE area, the three polarimetric radars allow for the precipitation patterns in the HOPE domain to be characterized in high resolution, which will be important for model evaluation. A 30 min rain accumulation over the inner HOPE area on 29 May 2013 shows that the three radar estimates result in an overall agreement of the rough precipitation pattern (Fig. 7). However, when we zoomed in on the details, we also noticed the minor differences between these patterns, e.g., lower precipitation observed by BoXPol and missing pixels near KiXPol and JuXPol. Bins close to KiXPol and JuXPol were contaminated by ground clutters, while the beam broadening and height at the larger ranges deteriorates the similarity between the BoXPol and $\mathrm{KiXPol} / \mathrm{JuXPol}$ estimates (Fig. 7). The different radar observation scenarios (i.e., at an elevation of $4.5^{\circ}$, JuXPol reaches $750 \mathrm{~m}$ above KiXPol and the time differences between the two radar measurements are up to $5 \mathrm{~min}$ ) also needs to be considered. A combination of the three radar observations will definitely be an advantage to reconstruct the precipitation patterns over the HOPE area in a future study. Since no adjustments of the $R-Z_{\mathrm{H}}$ and $R-$ $K_{\text {DP }}$ relations were made, these results are very promising. The three radar estimates together with the direct comparisons with the rain gauges and disdrometers allow for robust error estimates to be attributed to these precipitation fields, which will be valuable when compared with model simulations.

\section{Observed microphysical processes}

Falling hydrometeors are subject to growth and/or depletion by a range of microphysical processes which leave their fingerprints in the spatial and temporal evolution of several polarimetric moments. Since microphysical processes are simulated in atmospheric models with increasing detail, polarimetric radar observations can be used for model validations and can thus spur further improvements. In this section we present three cases where such microphysical processes could be observed by the radars and substantiated by MRR and disdrometer observations.

\subsection{Case 1: size sorting and coalescence}

On 26 April 2013, a cold front passed over Germany which came with a large band of stratiform rain that persisted from the morning hours until the end of the day. The daily rain accumulation recorded by the surface observations was about $3.5 \mathrm{~mm}$, with the precipitation lasting up to $8 \mathrm{~h}$ (Fig. 3). Six radiosondes launched at KITCube at 07:00, 09:00, 11:00, 13:00, 16:00 and 23:00 UTC, respectively, recorded a freezing level above $2100 \mathrm{~m}$ during daytime, which descended down to $830 \mathrm{~m}$ at about 23:00 UTC.

KiXPol preformed volume scans every $5 \mathrm{~min}$ on that day, with scan elevations ranging from 0.6 to $30^{\circ}$ (Table 1), while JuXPol performed RHIs in the direction of JOYCE every minute.

At 13:30 UTC KiXPol observed a precipitating cell approaching the radar from the southwest at a distance of about $10 \mathrm{~km}$ and which was moving towards JuXPol (Fig. 8). At 13:35 UTC the cell was within $8 \mathrm{~km}$ from KiXPol, where it started to disperse (not shown). RHIs performed with JuXPol at the azimuth direction $233.7^{\circ}$ nicely tracked the approaching cell (Fig. 9).

The high temporal resolution of the JuXPol RHIs allows for a detailed insight into the evolution of the precipitating cell. The cell was first observed by JuXPol at 13:00 UTC at about $45 \mathrm{~km}$ distance and kept moving towards JuXPol with low reflectivities at about $20 \mathrm{~dB}$ (not shown). At 13:29 UTC, JuXPol detected the precipitating cell entering its RHI at $20 \mathrm{~km}$ range (Fig. 9). In the center of the precipitating cell tilted towards the northeast by the wind shear (see Fig. 10), near-surface $Z_{\mathrm{DR}}$ values were up to $2 \mathrm{~dB}$, while $Z_{\mathrm{H}}$ was above $30 \mathrm{dBZ}$. $Z_{\mathrm{DR}}$ increases towards the ground concurrent with an increasing $Z_{\mathrm{H}}$. This behavior is a clear sign of coalescence, which shifts small raindrops to larger sizes and increases the mean raindrop size (Kumjian and Prat, 2014).

While the cell was moving towards JuXPol, its tilt led to a concentration of large rain drops at the leading edge of the precipitating cell, where their larger fall speed separates them from the smaller droplets which largely remain in the flow volume (e.g., Kumjian and Ryzhkov, 2012). From 13:29 to $13: 30 \mathrm{UTC}, Z_{\mathrm{DR}}$ at the leading edge of the cell is below $0.5 \mathrm{~dB}$ (Fig. 9). At 13:31 UTC, $Z_{\mathrm{DR}}$ begins increasing and 


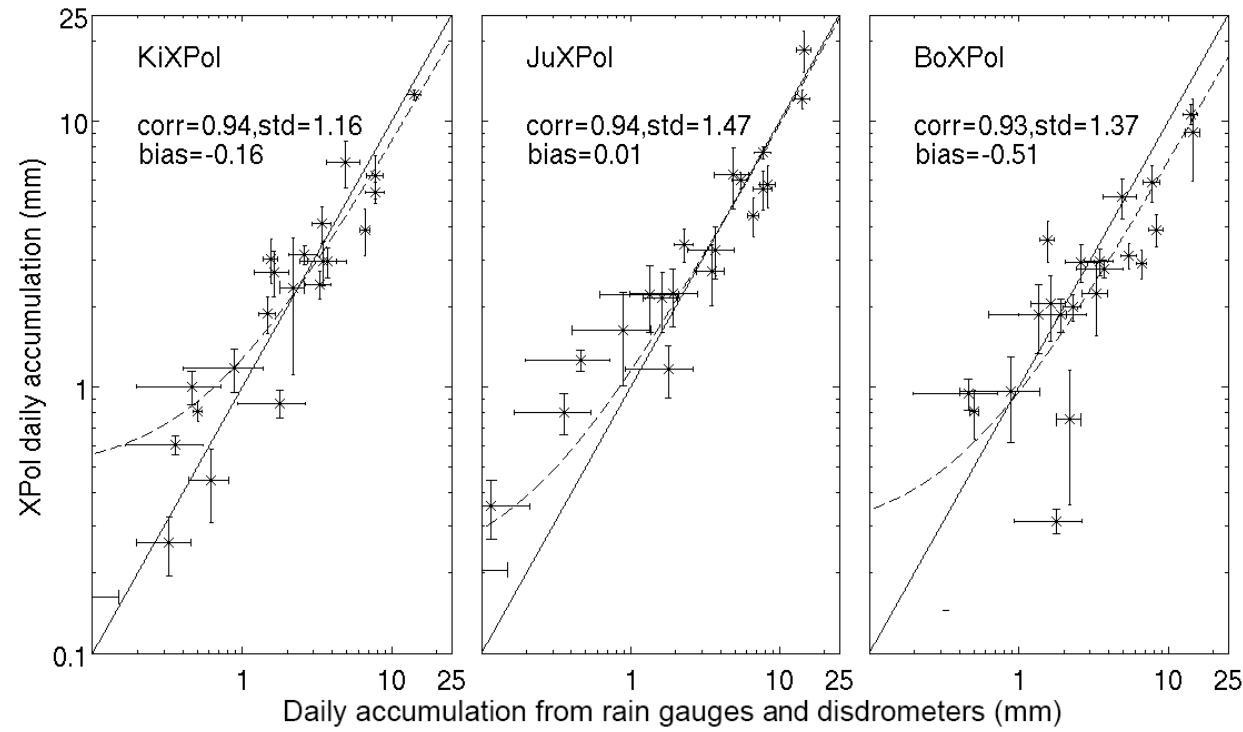

Figure 6. Mean daily radar-derived rain accumulation over the disdrometer/rain gauge locations, compared to the surface precipitation observed by the rain gauges and disdrometers in the HOPE area. The bars indicate the standard deviation of the estimates from the particular radar (vertical bars) and from the surface observations (horizontal bars). The dashed black line is the best linear fit of the daily rain accumulation on the logarithmic scale, while the solid black line is the $1: 1$ line.
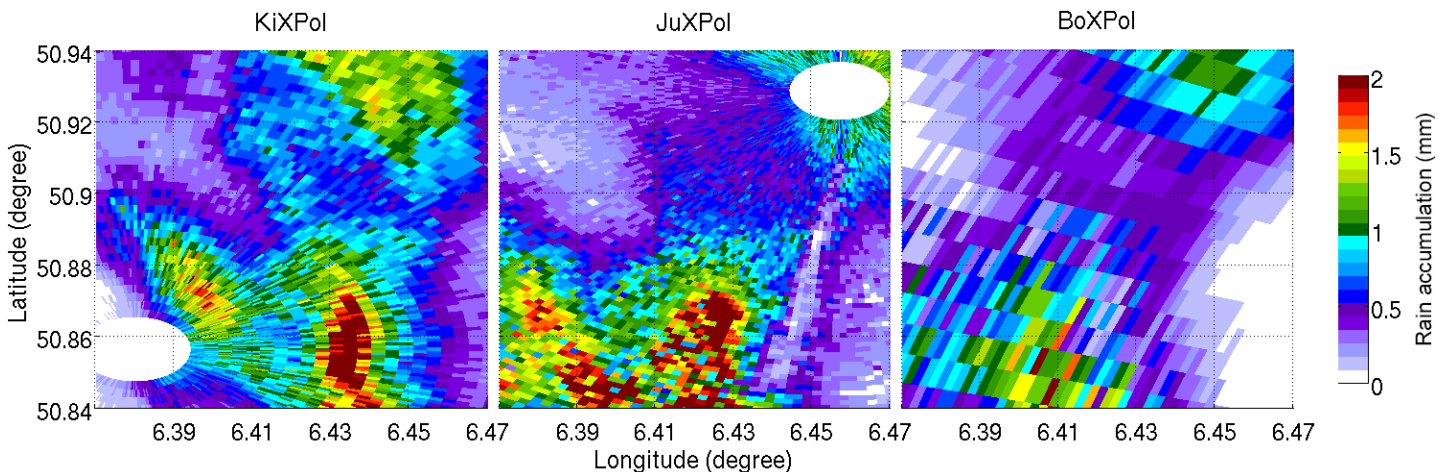

Figure 7. Rain accumulation over the HOPE area between 08:30 and 09:00 UTC (six PPIs) on 29 May 2013 observed by the three polarimetric radars.

later on reaches up to $2 \mathrm{~dB}$, while $Z_{\mathrm{H}}$ remains in the order of $15 \mathrm{dBZ}$ in that region. When the cell begins to dissipate as it moves forward, $Z_{\mathrm{DR}}$ decreases down to $\sim 1 \mathrm{~dB}$ both in the center and upstream of the precipitating cell.

\subsection{Case 2: size sorting due to vertical wind shear}

A second case on size sorting caused by the vertical wind shear was well captured by BoXPol on 17 May 2013. A deep low-pressure system reaching from the surface to $200 \mathrm{hPa}$ was found over the northeast Atlantic and the British Isles on the previous day, while a surface low was moving from the western Mediterranean to the north, towards central Europe. As a result, a complex pattern of fronts affected France and Germany due to the interaction of both systems. On 17 May 2013, a stationary front along with a through of warm air aloft passed over western Germany, moving eastwards. Low atmosphere levels were characterized by high humidity and a sharp west-east temperature gradient. A band of mostly stratiform rain affected southwestern and western Germany earlier in the day, while later on convective rain with lightning activity developed over southeast and central Germany. About $8 \mathrm{~mm}$ of rain accumulated over $6 \mathrm{~h}$ time spans, as recorded by the disdrometers (Fig. 3).

The precipitating cell moving westwards was captured by the BoXPol RHI scan. The melting layer can be easily identified by the enhanced $Z_{\mathrm{H}}$ and $Z_{\mathrm{DR}}$ at an altitude of $\sim 2.2 \mathrm{~km}$ in the RHI performed at an azimuth angle of $290^{\circ}$ (Fig. 11). Similar to the first case presented above, the strong $Z_{\mathrm{DR}}$ at the leading edge indicates the increase in mean raindrop size due to the accumulation of large raindrops by size sorting. 

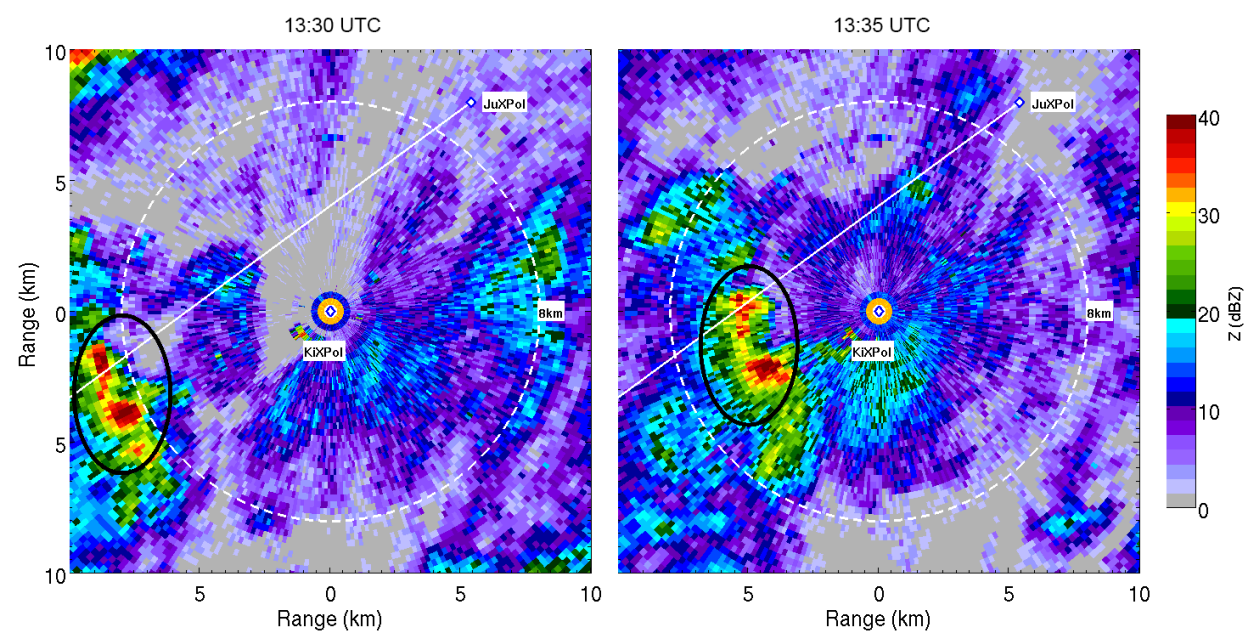

Figure 8. Reflectivity $\left(Z_{\mathrm{H}}\right)$ of KiXPol observed at an elevation angle of $3.5^{\circ}$ at 13:30 and 13:35 UTC on 26 April 2013. The precipitating cell examined in the text is highlighted by the black ellipse. The white solid line indicates the azimuth direction of the JuXPol RHIs, while the white dashed circle delineates the $8 \mathrm{~km}$ distance from KiXPol.

At $200 \mathrm{~m}$ distance from BoXPol, vertical profiles of DSDs were observed by an MRR. Figure 12 shows the time series of MRR-derived reflectivity (panel a) with the corresponding DSDs at an altitude of $600 \mathrm{~m}$ (panel b). The first cell of a precipitation system passed BoXPol and the MRR before 12:40 UTC, with reflectivities up to $40 \mathrm{dBZ}$ in the center, followed by a second peak with reflectivities up to $35 \mathrm{dBZ}$ (Fig. 12a). The derived DSDs indicate that large, fast-falling raindrops tend to concentrate at the upstream side of the cell, while raindrops less than $3 \mathrm{~mm}$ in diameter have a larger number concentration downstream (Fig. 12b). However, the coarse temporal resolution of BoXPol RHIs (every $5 \mathrm{~min}$ ) makes it difficult to directly compare the MRR observations with BoXPol over the MRR site.

The OTT Parsivel and Thies optical laser disdrometers collocated with the MRR also captured the precipitation event on that day (Fig. 12c-f). One Thies disdrometer was deployed with its transmitter-receiver line in the west-east direction (Thies 1) and the other in the south-north direction (Thies 2). For the surface DSDs shown in Fig. 12b-e, the largest raindrops collected by the two Thies disdrometers are below $4 \mathrm{~mm}$ after 12:39 UTC. Similar to MRR observations, however, the Parsivel observed larger raindrops up to $5 \mathrm{~mm}$ at an earlier time step since it was operated at a temporal resolution of $30 \mathrm{~s}$. This implies that a temporal resolution of better than $1 \mathrm{~min}$ is required to better interpret the DSD evolution caused by size sorting due to vertical wind shear and to improve the surface rainfall estimations.

The surface rain rates observed by the three disdrometers differ from the MRR observations at $600 \mathrm{~m}$ considering the spatial and temporal shifts (approximately $2 \mathrm{~min}$ ) (Fig. 12f). The maximum rain rate estimated from the MRR at $600 \mathrm{~m}$ is $\sim 8 \mathrm{~mm} \mathrm{~h}^{-1}$ at 12:38 UTC, with a second peak of $\sim 6 \mathrm{~mm} \mathrm{~h}^{-1}$ at 12:40 UTC. Considering the effects from size sorting and other possible microphysical processes, the rain rate at high altitudes is usually higher than at the surface. The two Thies disdrometers close to the Parsivel, which provide measurements at $1 \mathrm{~min}$ time interval, also show a smaller maximum rain rate near the ground. We thus conclude that the Parsivel is overestimating the rain rate (Fig. 12f). Nevertheless, these observations are consistent with the occurrence of the size-sorting process shown from the radar observations.

\subsection{Case 3: riming/aggregation processes observed by JuXPol}

On 29 May 2013 a cut-off process was underway over western and central Europe, resulting in a broad and well-defined upper level vortex. At lower levels the pressure distribution was more complex with several small surface lows and generally weak pressure gradients. One of these surface lows, initially situated over southern England at 00:00 UTC, moved to eastern France during the day. The corresponding cold front became quasi-stationary, as indicated by a sharp $\theta_{\mathrm{e}}$ (equivalent potential temperature) gradient over the Benelux region and western Germany (not shown). At 00:00 and 06:00 UTC frontogenetic forcing was strongest due to deformational processes in the vicinity of the front as it interacted with a second low over the northern half of Germany. This resulted in a subsequent reinforcement of frontal precipitation over the HOPE area until 12:00 UTC. During and after that intensification period the frontal temperature gradient gradually dissipated due to evaporative cooling and the advection of a colder maritime air mass also on the warm side of the front. As a consequence, frontal precipitation weakened by the end of the day.

The daily rain accumulation for 29 May 2013 recorded by the surface observations was $\sim 14 \mathrm{~mm}$, while precipitation 


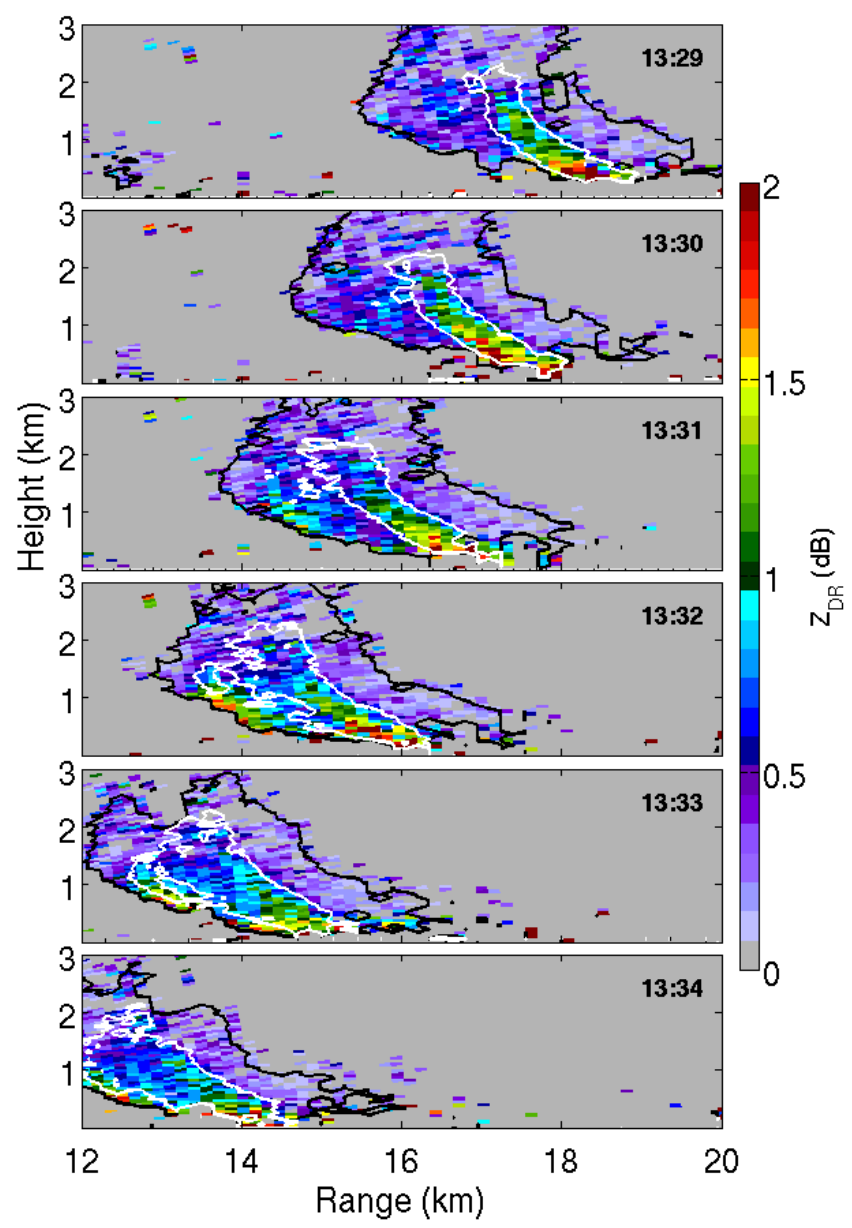

Figure 9. Sequence of RHIs of differential reflectivity $\left(Z_{\mathrm{DR}}\right)$ measured by JuXPol at an azimuth angle of $233.7^{\circ}$ between 13:29 and 13:34 UTC on 26 April 2013 (from top to bottom). The contour lines indicate reflectivity values $\left(Z_{\mathrm{H}}\right)$ of $15 \mathrm{dBZ}$ (black) and $30 \mathrm{dBZ}$ (white), respectively.

lasted up to $20 \mathrm{~h}$ (Fig. 3): this was the day with the longest rainy period which also led to the second largest daily rain accumulation during HOPE. Three radiosondes were launched at the location of KITCube, one at 23:00 UTC on 28 May and two at 11:00 and 23:00 UTC on 29 May. According to the soundings, the freezing level was located at $\sim 2.2 \mathrm{~km}$ at 23:00 UTC on 28 May 2013 and subsided down to $\sim 1.7 \mathrm{~km}$ at 11:00 UTC on 29 May 2013.

Figure 13 shows so-called quasi-vertical profiles (QVPs) of $Z_{\mathrm{H}}, Z_{\mathrm{DR}}, \rho_{\mathrm{HV}}$ and $K_{\mathrm{DP}}$ based on JuXPol measurements at $18^{\circ}$ elevation angle between 06:00 and 14:30 UTC. QVPs were first used by Trömel et al. (2014a) to reliably estimate backscatter differential phase, and Ryzhkov et al. (2016) further expanded the QVP methodology and demonstrated its multiple benefits. The QVPs of polarimetric variables are obtained by azimuthal averaging of the radar data collected during conical PPIs at higher antenna elevation angles in order to reduce statistical errors of the variables and assign their

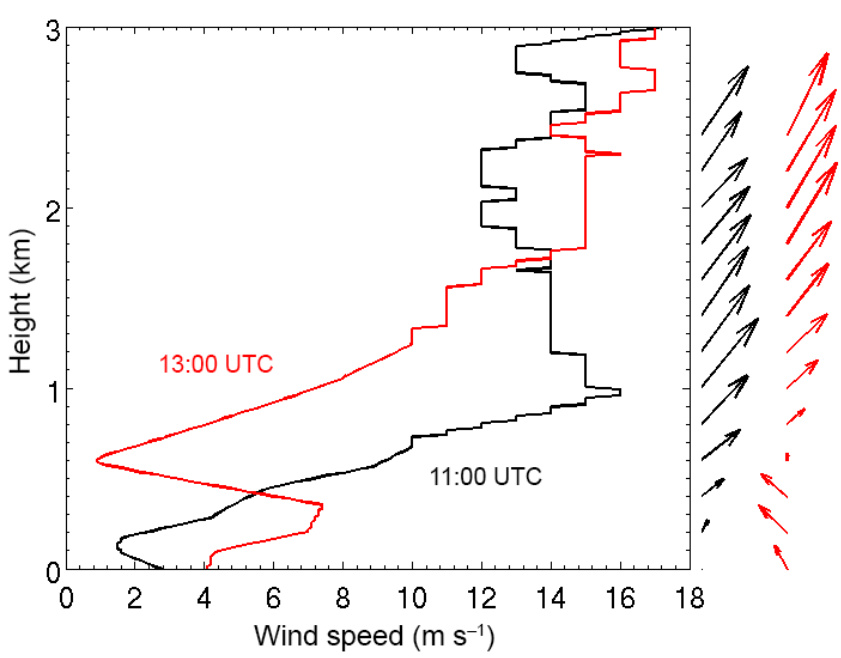

Figure 10. Wind profiles derived from radiosondes launched at KITCube at 11:00 and 13:00 UTC. The arrows on the right indicate the wind vector $\left(0^{\circ}\right.$ indicates the north), while their lengths are proportional to wind speed.

average vertical profiles to a conical volume in a time-height display. QVPs are especially beneficial for monitoring the temporal evolution of microphysical processes active on a larger scale.

The most striking feature in Fig. 13 is the descent of the melting layer from $1.8 \mathrm{~km}$ to $\sim 1.5 \mathrm{~km}$ height between 07:00 and 09:00 UTC. After 12:00 UTC, a region of enhanced $K_{\mathrm{DP}}$ above $3.5 \mathrm{~km}$ accompanied by $Z_{\mathrm{DR}}>1.2 \mathrm{~dB}$ aloft can be identified. Bands of enhanced $Z_{\mathrm{DR}}$ and bands of enhanced $K_{\mathrm{DP}}$ are both considered as signatures of dendritic growth (Kennedy and Rutledge, 2011). According to the radiosonde ascending at 11:00 UTC, the temperature zone of $-10^{\circ} \mathrm{C}$ to $-15^{\circ} \mathrm{C}$, which favors the growth of ice dendrites, is located between 3.8 and $4.7 \mathrm{~km}$. Thus, we may suspect that there are dendrites growing above $3.5 \mathrm{~km}$, especially after 12:00 UTC (Fig. 13).

When following the height evolution of polarimetric variable structures above the melting layer (ML) after 12:00 UTC (Fig. 13), riming/aggregation processes are indicated by enhancements of $Z_{\mathrm{H}}$ and $\rho_{\mathrm{HV}}$ above the ML, while $Z_{\mathrm{DR}}$ and $K_{\text {DP }}$ decrease with height in unison above the ML after 12:00 UTC (ellipses in Fig. 13). $Z_{\mathrm{DR}}$ and $K_{\mathrm{DP}}$ depressions aloft associated with increases in $Z_{\mathrm{H}}$ and $\rho_{\mathrm{HV}}$ above the ML suggest increases of ice particle mean sizes due to riming and/or aggregation. Recently, Moisseev et al. (2015) argued that the processes responsible for enhanced $K_{\mathrm{DP}^{-}}$and $Z_{\mathrm{DR}^{-}}$ bands might be different: they advocated that the $K_{\mathrm{DP}}$ bands are caused by high number concentrations of oblate relatively dense ice particles (early aggregates) and are linked to the onset of aggregation processes, while $Z_{\mathrm{DR}}$ bands in the absence of $K_{\mathrm{DP}}$ bands are observed when crystal growth is the dominant snow growth mechanism and the number concentration is lower. Following their arguments, it can also be speculated 

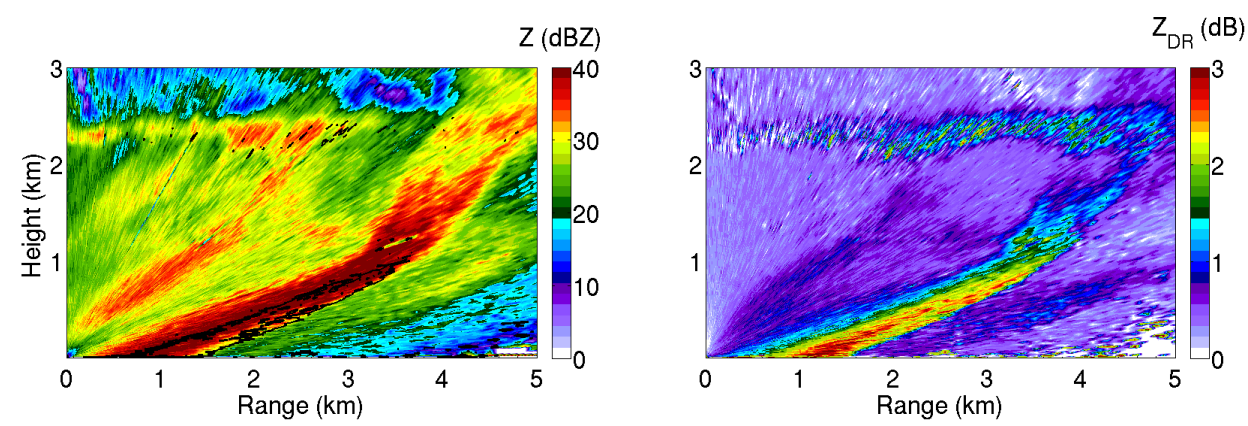

Figure 11. Reflectivity $\left(Z_{\mathrm{H}}\right.$, left) and differential reflectivity $\left(Z_{\mathrm{DR}}\right.$, right) observed by BoXPol at an azimuth angle of $290^{\circ}$ at $12: 40 \mathrm{UTC}$ on 17 May 2013. The black isoline in the left panel indicates the $2 \mathrm{~dB} Z_{\mathrm{DR}}$ contour line.

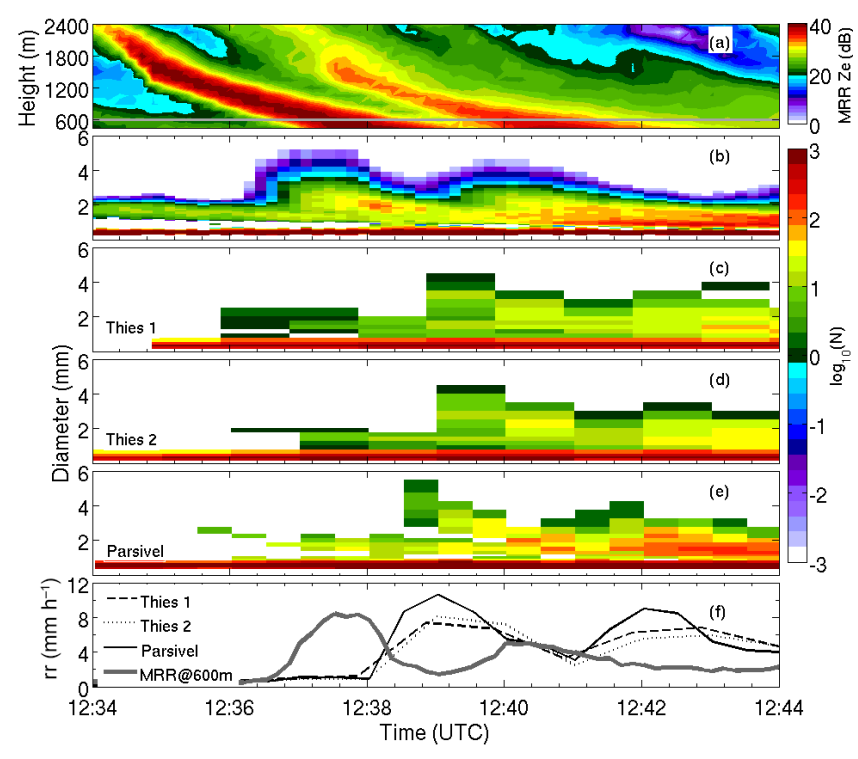

Figure 12. Different instrument observations located within distances of $5 \mathrm{~m}(200 \mathrm{~m})$ from the BoXPol location in Bonn, Germany, between 12:34 and 12:44 UTC on 17 May 2013. (a) Reflectivity observed by vertically pointing micro rain radars (MRRs). The gray horizontal solid line indicates the $600 \mathrm{~m}$ height level. (b) MRR-observed DSDs at $600 \mathrm{~m}$ altitude. (c) DSDs observed by a Thies disdrometer with its transmitter and receiver line pointing along the east-west direction (Thies 1). (d) Same as (c) but for a Thies disdrometer pointing along the south-north direction (Thies 2). (e) Same as (c) except for an OTT Parsivel disdrometer. (f) Rain rate observed by an MRR at $600 \mathrm{~m}$ height and the three disdrometers collocated with the MRR at the BoXPol station.

that aggregation processes are ongoing near the end of the observation period shown in Fig. 13.

Discrimination between riming and aggregation is important for aviation security, since riming implies the existence of supercooled liquid water above the freezing level, which could result in dangerous icing on aircrafts. Riming is also associated with embedded updrafts and convective development and thus precipitation enhancement. In the presence of such updrafts, enhanced condensation of water vapor occurs and leads to small liquid droplets which may be accreted by dry snowflakes. These rimed snowflakes may grow fast and reach large sizes with higher terminal velocity before they fall through the ML. Due to their enhanced terminal velocity, they melt at a lower height and lead to the "sagging" signature of the bright band in terms of $Z_{\mathrm{DR}}$ and $\rho_{\mathrm{HV}}$ (Ryzhkov et al., 2016).

In Fig. 13, reduced $Z_{\mathrm{DR}}$ combined with enhanced $Z_{\mathrm{H}}$ and $\rho_{\text {HV }}$ above the ML occurs at times, and "sagging" signatures are also clearly visible at around 12:00 and 13:00 UTC (the magenta arrows in Fig. 13b). Starting from the bottom of the $Z_{\mathrm{DR}}$ and $K_{\mathrm{DP}}$ bands at about $3 \mathrm{~km}$ height at 12:00 UTC, $Z_{\mathrm{DR}}$ decreases and $Z$ increases downwards, most probably due to aggregation and/or riming. Here $Z_{\mathrm{DR}}$ reduces down to a few tenths of a decibel just above the level where melting starts. However, this reduction is expected to be more intense for riming than for aggregation. Riming makes the ice particles more spherical leading to a lower $Z_{\mathrm{DR}}$ by $0.1-0.3 \mathrm{~dB}$ (Ryzhkov et al., 2016). Thus, we speculate that riming causes the "sagging" effects of $Z_{\mathrm{DR}}$ and $\rho_{\mathrm{HV}}$ combined with relatively low $Z_{\mathrm{DR}}$ above the ML around 12:00 and 13:00 UTC. To more reliably distinguish between riming and aggregation, we require additional measurements indicative, for example, of associated updrafts and supercooled liquid water above the ML, which could be provided by additional microwave radiometers and cloud radars.

The discussed examples have clearly shown how polarimetric radars can be used to identify and distinguish between different microphysical processes, such as warm rain processes and ice particle formation and growth. Converting the output of numerical weather prediction models into polarimetric radar variables and using a polarimetric forward radar operator would provide an opportunity to validate the representation of the discussed microphysical processes in such models.

\section{Conclusions}

This study presents a summary of rainfall observations and some examples of related microphysical processes occurring 

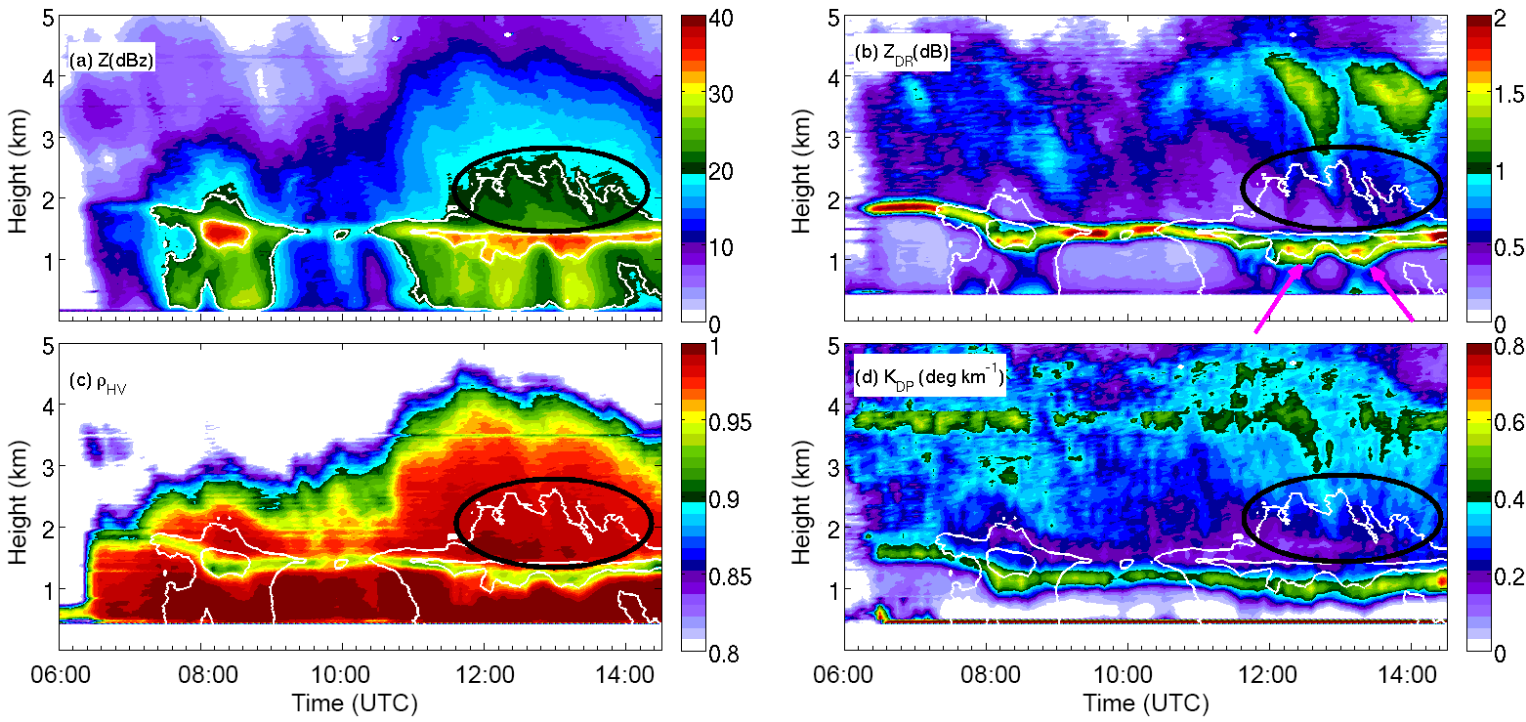

Figure 13. (a) Time series of quasi-vertical profiles (QVPs) of $Z_{\mathrm{H}}$ derived from PPIs measured with JuXPol at $18^{\circ}$ elevation on 29 May 2013 between 06:00 and 14:30 UTC. The white lines indicate the 20 and $30 \mathrm{dBZ}$ contours of $Z_{\mathrm{H}}$. (b, c, d) The same time series as (a) but for $Z_{\mathrm{DR}}$, $\rho_{\mathrm{HV}}$ and $K_{\mathrm{DP}}$, respectively. The black ellipses highlight the area for aggregation/riming, while the magenta arrows in panel (b) indicate the instances of $Z_{\mathrm{DR}}$ sagging (see text for detail).

during HOPE between 1 April and 31 May 2013. At that time, three X-band polarimetric Doppler radars observed the central HOPE area of about $5 \mathrm{~km} \times 5 \mathrm{~km}$, over which a surface network of rain gauges, disdrometers and MRRs was deployed to assess the accuracy of the radar-based precipitation observations and to demonstrate the capability of polarimetric radars to detect microphysical processes. Rainfall accumulations at the daily and even hourly scale were surprisingly consistent between the different observations, demonstrating the high quality of QPE based on $R-Z$ and $R-K_{\mathrm{DP}}$ relations, at least for the low-intensity rainfall events prevalent during HOPE.

The combined observations of polarimetric radars and collocated instruments demonstrated the ability of radar polarimetry to detect several microphysical processes by socalled polarimetric fingerprints during the development and evolution of precipitation systems. These fingerprints clearly identify microphysical processes like coalescence, size sorting and riming/aggregation. Size sorting by wind shear was well captured, for example, by the JuXPol and BoXPol RHIs and corroborated by the collocated MRR and disdrometer observations. While there were clear signs of other processes like riming and aggregation, a distinction between these two processes is still difficult with the available observations. Doppler velocities in the vertical-pointing mode were analyzed, but the observed values (between 1 and $2 \mathrm{~m} \mathrm{~s}^{-1}$ ) still make the distinction ambiguous. Furthermore, the exact time from the QVP and vertical-pointing scans cannot be matched, and one has to be careful when comparing the QVP with vertical scans. Additional analysis in conjunction with other independent observations (e.g., from microwave radiometers, lidars and cloud radars which were deployed at the JOYCE site) is also required for a better distinction between riming and aggregation, which is the focus of an ongoing study.

Acknowledgements. This research was funded by the Federal Ministry of Education and Research in Germany (BMBF) through the research program "High Definition Clouds and Precipitation for Climate Prediction - HD $(\mathrm{CP})^{2}$ " (FKZ: 01LK1219A and 01LK1210A). We thank Martin Lennefer and Kai Muehlbauer at University of Bonn and the SFB/TR 32 (Transregional Collaborative Research Centre 32, http://www.tr32.de/), funded by the German Research Foundation (DFG), for maintaining the instruments and making the radar data available. We thank Patric Seifert from the Leibniz Institute for Tropospheric Research (TROPOS) for providing the OTT Parsivel data from the LACROS station. We also acknowledge Norbert Kalthoff and his colleagues from Karlsruhe Institute of Technology (KIT) for providing KiXPol observations and the observation data from the KITCube station during HOPE.

Edited by: H. Russchenberg

\section{References}

Andric, J., Kumjian, M. R., Zrnic, D. S., Straka, J. M., and Melnikov, V. M.: Polarimetric signature above the melting layer in winter storms: An observational and modeling study, J. Appl. Meteor. Clim., 52, 682-700, 2013.

Bechini, R., Baldini, L., and Chandrasekar, V.: Polarimetric Radar Observations in the Ice Region of Precipitating Clouds at C- 
Band and X-Band Radar Frequencies, J. Appl. Meteor. Clim., 52, 1147-1169, 10.1175/jamc-d-12-055.1, 2013.

Brandes, E. A., Zhang, G., and Vivekanandan, J.: Experiments in Rainfall Estimation with a Polarimetric Radar in a Subtropical Environment, J. Appl. Meteor., 41, 674-685, 2002.

Diederich, M., Ryzhkov, A., Simmer, C., Zhang, P., and Trömel, S.: Use of Specific Attenuation for Rainfall Measurement at XBand Radar Wavelengths. Part I: Radar Calibration and Partial Beam Blockage Estimation, J. Hydrometeorol., 16, 487-502, doi:10.1175/jhm-d-14-0066.1, 2015a.

Diederich, M., Ryzhkov, A., Simmer, C., Zhang, P., and Trömel, S.: Use of Specific Attenuation for Rainfall Measurement at XBand Radar Wavelengths. Part II: Rainfall Estimates and Comparison with Rain Gauges, J. Hydrometeorol., 16, 503-516, doi:10.1175/jhm-d-14-0067.1, 2015b.

Giangrande, S. E. and Ryzhkov, A. V.: Estimation of Rainfall Based on the Results of Polarimetric Echo Classification, J. Appl. Meteor. Clim., 47, 2445-2462, doi:10.1175/2008jamc1753.1, 2008.

Giangrande, S. E., Krause, J. M., and Ryzhkov, A. V.: Automatic Designation of the Melting Layer with a Polarimetric Prototype of the WSR-88D Radar, J. Appl. Meteor. Clim., 47, 1354-1364, doi:10.1175/2007jamc1634.1, 2008.

Hubbert, J. and Bringi, V. N.: An Iterative Filtering Technique for the Analysis of Copolar Differential Phase and Dual-Frequency Radar Measurements, J. Atmos. Ocean. Tech., 12, 643-648, doi:10.1175/1520-0426(1995)012<0643:aiftft>2.0.co;2, 1995.

Kalthoff, N., Adler, B., Wieser, A., Kohler, M., Träumner, K., Handwerker, J., Corsmeier, U., Khodayar, S., Lambert, D., Kopmann, A., Kunka, N., Dick, G., Ramatschi, M., Wickert, J., and Kottmeier, C.: KITcube - a mobile observation platform for convection studies deployed during HyMeX, Meteorol. Z., 22, 633647, doi:10.1127/0941-2948/2013/0542, 2013.

Kennedy, P. C., and Rutledge, S. A.: S-Band Dual-Polarization Radar Observations of Winter Storms, J. Appl. Meteor. Clim., 50, 844-858, doi:10.1175/2010jamc2558.1, 2011.

Kumjian, M. R. and Prat, O. P.: The Impact of Raindrop Collisional Processes on the Polarimetric Radar Variables, J. Atmos. Sci., 71, 3052-3067, doi:10.1175/JAS-D-13-0357.1, 2014.

Kumjian, M. R. and Ryzhkov, A. V.: The Impact of Evaporation on Polarimetric Characteristics of Rain: Theoretical Model and Practical Implications, J. Appl. Meteor. Clim., 49, 1247-1267, 10.1175/2010JAMC2243.1, 2010.

Kumjian, M. R. and Ryzhkov, A. V.: The Impact of Size Sorting on the Polarimetric Radar Variables, J. Atmos. Sci., 69, 2042-2060, doi:10.1175/JAS-D-11-0125.1, 2012.

Kumjian, M. R., Ganson, S. M., and Ryzhkov, A. V.: Freezing of Raindrops in Deep Convective Updrafts: A Microphysical and Polarimetric Model, J. Atmos. Sci., 69, 3471-3490, doi:10.1175/JAS-D-12-067.1, 2012.

Li, X. and Srivastava, R. C.: An Analytical Solution for Raindrop Evaporation and Its Application to Radar Rainfall Measurements, J. Appl. Meteorol., 40, 1607-1616, 2001.

Löhnert, U., Schween, J. H., Acquistapace, C., Ebell, K., Maahn, M., Barrera-Verdejo, M., Hirsikko, A., Bohn, B., Knaps, A., O'Connor, E., Simmer, C., Wahner, A., and Crewell, S.: JOYCE: Jülich Observatory for Cloud Evolution, B. Am. Meteorol. Soc., 96, 1157-1174, doi:10.1175/bams-d-14-00105.1, 2015.
Marshall, J. S. and Palmer, W. M. K.: The Distribution of Raindrops with Size, J. Meteorol., 5, 165-166, doi:10.1175/15200469(1948)005<0165:tdorws>2.0.co;2, 1948.

Moisseev, D. N., Lautaportti, S., Tyynela, J., and Lim, S.: Dual-polarization radar signatures in snowstorms: role of snowflake aggregation, J. Geophys. Res., 120, 12644-12655, doi:10.1002/2015JD023884, 2015.

Ryzhkov, A., Diederich, M., Zhang, P., and Simmer, C.: Potential Utilization of Specific Attenuation for Rainfall Estimation, Mitigation of Partial Beam Blockage, and Radar Networking, J. Atmos. Ocean. Tech., 31, 599-619, doi:10.1175/jtech-d-1300038.1, 2014.

Ryzhkov, A., Zhang, P., Reeves, H., Kumjian, M., Tschallener, T., Simmer, C. and Trömel, S.: Quasi-vertical profiles - a new way to look at polarimetric radar data, J. Atmos. Ocean. Tech., 33, 3551-3562, 2016.

Ryzhkov, A. V. and Zrnic, D. S.: Discrimination between Rain and Snow with a Polarimetric Radar, J. Appl. Meteorol, 37, 1228-1240, doi:10.1175/15200450(1998)037<1228:dbrasw>2.0.co;2, 1998.

Simmer, C., Masbou, M., Thiele-Eich, I., Amelung, W., Bogena, H., Crewell, S., Diekkrüger, B., Ewert, F., Franssen, H.-J. H., Huisman, J. A., Kemna, A., Klitzsch, N., Kollet, S., Langensiepen, M., Löhnert, U., Mostaquimur Rahman, A. S. M., Rascher, U., Schneider, K., Schween, J., Shao, Y., Shrestha, P., Stiebler, M., Sulis, M., Vanderborght, J., Vereecken, H., van der Kruk, J., Waldhoff, G., and Zerenner, T.: Monitoring and Modeling the Terrestrial System from Pores to Catchments - the Transregional Collaborative Research Center on Patterns in the SoilVegetation-Atmosphere System, B. Am. Meteorol. Soc., 96, 1765-1786, doi:10.1175/bams-d-13-00134.1, 2015.

Trömel, S., Ryzhkov, A. V., Zhang, P., and Simmer, C.: Investigations of Backscatter Differential Phase in the Melting Layer, J. Appl. Meteorol. Clim., 53, 2344-2359, doi:10.1175/jamc-d-140050.1, 2014a.

Trömel, S., Ziegert, M., Ryzhkov, A. V., Chwala, C., and Simmer, C.: Using Microwave Backhaul Links to Optimize the Performance of Algorithms for Rainfall Estimation and Attenuation Correction, J. Atmos. Ocean. Tech., 31, 1748-1760, doi:10.1175/jtech-d-14-00016.1, 2014b.

Zacharias, S., Bogena, H., Samaniego, L., Maude, M., Fuss, R., Putz, T., Frenzel, M., Schwank, M., Baessler, C., ButterbachBahl, K., Bens, O., Borg, E., Brauer, A., Dietrich, P., Hajnsek, I., Helle, G., Kiese, R., Kunstmann, H., Klotz, S., Munch, J. C., Papen, H., Priesack, E., Schmid, H. P., Steinbrecher, R., Rosenbaum, U., Teutsch, G., and Vereecken, H.: A Network of Terrestrial Environmental Observatories in Germany, Vadose Zone J., 10, 955-973, doi:10.2136/vzj2010.0139, 2011.

Zhang, G., Vivekanandan, J., and Brandes, E.: A method for estimating rain rate and drop size distribution from polarimetric radar measurements, IEEE Trans. Geosci. Remote Sens., 39, 830-841, doi:10.1109/36.917906, 2001.

Zrnić, D. S. and Ryzhkov, A. V.: Polarimetry for Weather Surveillance Radars, B. Am. Meteorol. Soc., 80, 389-406, doi:10.1175/1520-0477(1999)080<0389:pfwsr>2.0.co;2, 1999.

Zrnić, D. S., Keenan, T. D., Carey, L. D., and May, P.: Sensitivity Analysis of Polarimetric Variables at a 5-cm Wavelength in Rain, J. Appl. Meteorol., 39, 1514-1526, doi:10.1175/15200450(2000)039<1514:saopva>2.0.co;2, 2000. 